\title{
Assessment of climate change exposure of tourism in Hungary using observations and regional climate model data
}

\author{
Attila KOVÁCS ${ }^{1}$ and ANDREa KIRÁLY²
}

\begin{abstract}
Climate constitutes key resources for tourism since it influences the range of tourism activities and the development of tourism supply. Tourism is highly sensitive to changes in climate elements. It is extremely important for adaptation strategy-making to explore whether the tourism climate conditions in a given region and at a specific time are appropriate and how they may change in the future. This is described by the exposure of the tourism sector to climate conditions and climate change. In this study, we analyse the exposure of tourism for Hungary on a district level and every month (from March to November) with the help of the modified Tourism Climate Index. First, the present conditions are evaluated based on a gridded observational database CarpatClim-HU, which forms the basis for assessing the future conditions. Afterwards, the expected future circumstances are analysed using regional climate model outputs. In order to interpret the uncertainties of the climate projections properly, we use two different model results (HIRHAM5 and RACMO22E) relying on two emission scenarios (RCP4.5 and RCP8.5). The results have demonstrated that the most favourable conditions are found in spring (MAM) and autumn (SON), while in summer (JJA) a decline in climate potential is observed. According to the future tendencies, generally, a decline is expected between May and September, but the other investigated months usually bring an improvement. For a given emission scenario, the expected trend is quite similar for the two model experiments, while for a given climate model, the use of RCP8.5 scenario indicates larger changes than RCP4.5. The results prove that climate change will have an obvious impact on tourism potential in Hungary, and therefore tourism strategy development has to take into account this effect more than before.
\end{abstract}

Keywords: climate change, climate exposure, tourism, regional climate model, modified Tourism Climate Index, districts of Hungary

Received May 2021, accepted August 2021.

\section{Introduction}

Tourism is one of the most important and dynamically developing sectors of the global and Hungarian economy. Weather and climate are key resources for tourism, and in certain cases they serve as tourist attractions (Perry, A.H. 1997; Gómez Martín, B. 2005). The complex interactions between atmospheric climate elements influence the development of tourism supply, sometimes limiting tourism activities or on occasion encour- aging the development of alternative tourism products. The climatic conditions of a given destination can provide substantial motivation to visit the site (LoHmanN, M. and KaIm, E. 1999; KozaK, M. 2002) and play a key role in the decision-making processes of destination selection (Hamilton, J.M. and LaU, M.A. 2005; Sсотt, D. and Lemieux, C. 2010).

Observations from recent decades have shown that climate change has an impact on natural and human systems around the world. Tourism is one of the economic sec-

\footnotetext{
${ }^{1}$ Department of Climatology and Landscape Ecology, University of Szeged, Egyetem u. 2. HU-6722 Szeged, Hungary. E-mail: kovacsattila@geo.u-szeged.hu

${ }^{2}$ Modelling Unit, Hungarian Meteorological Service, Kitaibel Pál u. 1. HU-1024 Budapest, Hungary. E-mail: andrea.kiraly.elte@gmail.com
} 
tors that is most exposed and sensitive to environmental change, including climate change (UNWTO 2008; Sсотт, D. et al. 2012).

Climate change has direct and indirect impacts on tourist destinations and the tourism industry (UNWTO 2008). Indirect effects include sea-level rise, changes in biodiversity, an increase in the frequency of extreme weather events, changes in snowfall or heat load, among others. They have a significant negative impact on several areas, including tourism infrastructure, time of travel, tourism activity, water resources, ecotourism and epidemics. The direct effects can be identified by the modification of the different climate parameters (averages, extremes) due to climate change. As a result, climate change can alter the global or regional spatial and temporal distribution of climate resources, resulting in a change in international or domestic tourism flows in space and time (Amelung, B. and Moreno, A. 2012; Rutty, M. and Scotт, D. 2014). As another direct effect, climate change negatively affects many outdoor activities that are important for tourism through extreme weather events.

One of the key factors for sustainable tourism development is to be aware of whether the climate conditions in a given region and at a specific time are appropriate for tourist activities and what can be expected in future decades. For the development and implementation of targeted adaptation strategies to climate change, it is essential to examine the vulnerability of the tourism sector to climate change and the different components of the vulnerability. Vulnerability expresses the extent to which the sector is susceptible to or unable to cope with the adverse effects of climate change (SCHNeIder, S.H. et al. 2007). Each region is vulnerable to changes in different ways and to different degrees (PÁlvölgyi, T. et al. 2010). The territorial and sectoral strategic integration of adaptation to climate change requires a wide range of information on territorial, environmental, economic and social vulnerability to change.

Several tools have been developed to analyse the complex climate vulnerability of tourism. The most commonly used tool is the CIVAS (Climate Impact and Vulnerability Assessment Scheme) model, developed by the CLAVIER international climate research project. The model relies on the approach published in the Fourth Assessment Report of the Intergovernmental Panel on Climate Change, IPCC (IPCC, 2007). It provides a uniform conceptual and methodological framework for quantitative climate impact assessments. The theoretical structure of the CIVAS model is presented in Figure 1.

The model describes climate change vulnerability as a complex indicator that identifies complex natural, economic and social vulnerability caused by climate change by integrating exposure, sensitivity and adaptability indicators (see Figure 1). The advantage of the model is the quantifiability of the complex vulnerability and its components, which makes it possible to compare different tourism activities, destinations and periods objectively.

One of the initial steps in the CIVAS model is the determination of the exposure of tourism to climate conditions or climate change. Exposure is based on the climatic elements (conditions) of the given geographical area and their changes (see Figure 1). Numerical values for exposure are provided by measured or observed meteorological data as well as estimates from global climate models (GCMs) or regional climate models (RCMs). Therefore, information from observations and from climate models is an important initial element of objective-based exposure or impact assessment and vulnerability studies.

Projections based on climate models are, in all cases, burdened with uncertainties, which result from the natural variability of the climate system and the approximate description of the physical processes included in the models. In addition, there is no definite information on how socio-economic processes affecting the climate system may develop in the future (SzÉPszó, G. et al. 2016). In order to understand future climatic conditions and impacts on different sectors, including tourism, it is necessary to take into account the uncertainties of climate projections, too. 


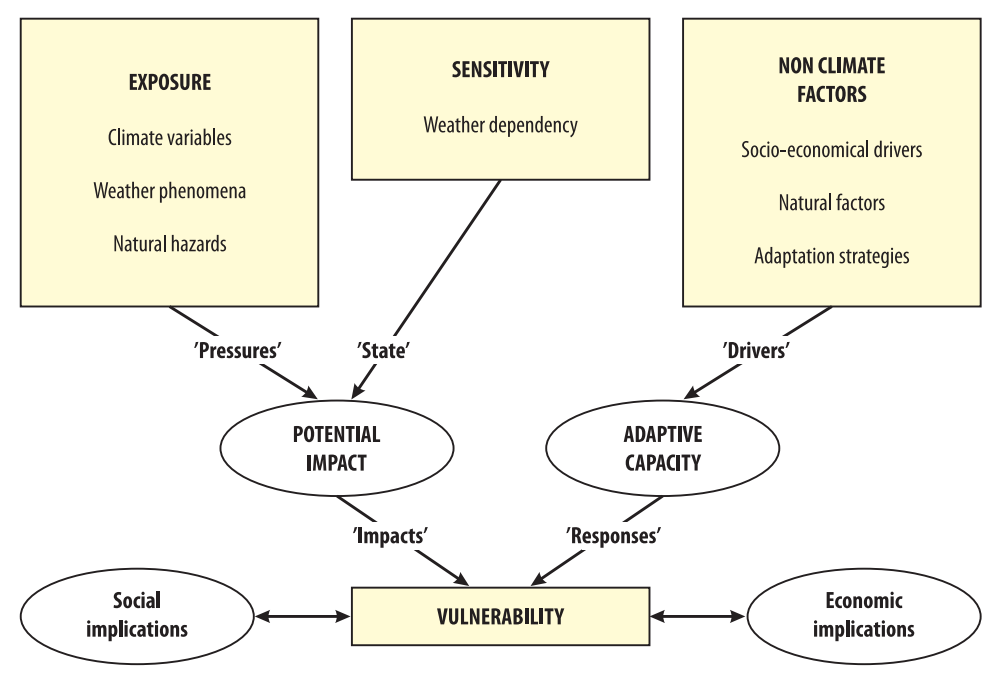

Fig. 1. The theoretical structure of the CIVAS model. Source: Self-edited scheme based on PÁLvöLGYI, T. et al. 2010.

Results based on a single climate model experiment performed on a single emission scenario do not serve as a reliable forecast of the expected conditions and do not provide the opportunity to quantify the uncertainties in the projections. A qualitative improvement is the application of a well-selected model ensemble, based on multiple scenarios, implemented with multiple regional models driven by different global models. This method can ensure a balanced presentation of uncertainties arising from the choice of different scenarios or from the differences in RCMs, or the GCMs that provide the boundary condition for RCMs (SzÉPSzó, G. et al. 2016).

Observational and model data include a wide range of climate data. The exposure of the tourism sector to climate is usually characterised not by individual meteorological parameters but mostly by special complex tourism climate assessment tools (ENDLER, C. et al. 2010; Amelung, B. and Nicholls, S. 2014). These tools integrate several climate data relevant for tourism in various ways. They range from simple indices that require only a few climatic variables (e.g. the indices of Mieczкowski, Z.T. 1985; Kovács, A. et al.
2016; Sсотт, D. et al. 2016) to complex assessment matrices (DE FreitAs, C.R. et al. 2008) and to evaluation schemes (MATZARAKIS, A. 2007).

The number of studies analysing the climate exposure of the tourism sector for the area of Hungary or for some parts of the country is very low, and they have primarily examined the present conditions (e.g. Németh, Á. 2013; Kovács, A. and Unger, J. 2014a, b; KovÁcs, A. et al. 2016). The expected future circumstances based on RCM outputs were only evaluated by Kovács, A. (2017), Kovács, A. et al. (2017), and Sütö, A. and Fejes, L. (2019).

In this study, we analyse the exposure of the tourism sector to climate change in Hungary with the help of a tourism climate index. First, the present conditions are examined based on a gridded observational database, which forms the basis for assessing future circumstances. Afterwards, the expected future conditions are studied, for which we use regional climate model outputs. In order to interpret the uncertainties of the climate projections properly, we use two different RCM results relying on two emission scenarios. 


\section{Data and methods}

The climate of Hungary is highly varied, as it is affected by the oceanic climate with balanced temperature and precipitation, the continental climate with extreme temperatures and low precipitation, and the Mediterranean climate with aridity in summer and rainy conditions in winter. Another major determinant of the climate is the topography. As the country is located in the Carpathian Basin and most of its surface is flat or gently undulating at low elevations, the impact of the Carpathians is of considerable importance. In most of the country, the annual mean temperature is between 10 and $11{ }^{\circ} \mathrm{C}$, which is determined by the geographical location, the altitude, and the distance from the sea. Based on the period 1971-2000, the first weeks of January are the coldest, while late July and early August are the warmest periods of the year. The variability of temperature from year to year is generally smaller in the summer months than in the winter months (https://www.met.hu/en/ eghajlat/magyarorszag_eghajlata/). In the period 1961-2010, the temperature was found to increase in every season and on an annual basis, particularly in the last three decades, thus, confirming the trends occurring throughout Europe (SPINONI, J. et al. 2015). In this period, the number of warm nights and warm days was significantly increasing, showing a universal warming trend in the region. In the annual occurrence of cold nights, a large part of the region experienced a significant decrease (LAKAтоs, M. et al. 2016).

The long-term average annual precipitation is $500-750 \mathrm{~mm}$ in the country, but there are significant differences among the various regions due to the topography and the influences of the Mediterranean Sea and the Atlantic Ocean. Based on the period 1971-2000, the wettest parts of the country (more than $700 \mathrm{~mm}$ ) are the southwestern region as well as the higher areas, while the lowest precipitation (less than 500 $\mathrm{mm}$ ) is detected in the middle part of the Great Plain. The average annual precipita- tion decreases from southwest to northeast. Precipitation is highest between May and July and lowest between January and March. Precipitation is fairly variable, with considerable fluctuations from year to year. There may be a lack of precipitation in any month (https://www.met.hu/en/eghajlat// magyarorszag_eghajlata/). The risk of aridity and drought is high in Hungary (SPINONI, J. et al. 2013; Gavrilov, M.B. et al. 2020). In the period 1961-2010, precipitation showed no significant trend, though it has increased slightly on an annual basis in the last two decades. The figures, thus, show a small increase relative to the 1980s, which was the driest decade analysed (SPINONI, J. et al. 2015).

For the quantification of the exposure of tourism to climate change, in this study the modified version of the widely used Tourism Climate Index (TCI) of Mieczkowski, Z.T. (1985) was applied (Kovács, A. et al. 2016, 2017), hereinafter referred to as $m$ TCI. The TCI and $m$ TCI quantify the impact of climatic conditions on general outdoor tourism activities (e.g. sightseeing, recreation and other light physical activities outdoors).

The original form of the TCI consists of five sub-indices, which in turn rely on monthly values (monthly means and monthly sums in the case of precipitation) of seven basic climate parameters relevant for tourism: daily maximum air temperature, minimum relative humidity, mean air temperature, mean relative humidity, precipitation sum, sunshine duration and wind speed. From these parameters, precipitation sum, sunshine duration and wind speed values are rated in itself with special rating score systems, from values zero (unfavourable) to five (optimal), forming sub-indices $R, S$ and $W$, respectively. The temperature and humidity data are combined into two sub-indices, the so-called daily comfort index (CIa) and daytime comfort index $(C I d)$. These sub-indices describe the thermal comfort conditions for the whole day (CIa) and at the warmest period of the day (CId). Correspondingly, CIa is based on the daily mean air temperature and mean relative humidity, while CId rates the effect of the 
daily maximum temperature and minimum relative humidity. In fact, the rating systems of CId and CIa rely on the combined effect of the corresponding temperature and humidity on thermal comfort, which is expressed in the form of the Effective Temperature (ET). $E T$ is one of the earliest and simplest empirical thermal indices, and it takes into account the temperature and humidity variables only (Houghten, F.C. and Yaglou, C.P. 1923). The rating scores of the ET values in the TCI range from minus three to five.

Finally, the overall TCI value is obtained by calculating the weighted sum of the subindices (CId, CIa, R, S and $W$ ) with the use of weight factors that express their relative importance within the overall climate evaluation (Mieczkowski, Z.T. 1985; Kovács, A. et al. 2016, 2017):

$$
T C I=2(4 C I d+C I a+2 R+2 S+W)
$$

The TCI values are classified on a predefined scale of -20 to +100 , with higher values indicating a more favourable climatic potential for outdoor tourism activities (Mieczкowski, Z.T. 1985) (Table 1).

Table 1. The evaluation system of the Tourism Climate Index (TCI)

\begin{tabular}{l|l}
\hline TCI values & \multicolumn{1}{|c}{ Descriptive categories } \\
\hline $90-100$ & ideal \\
$80-89$ & excellent \\
$70-79$ & very good \\
$60-69$ & good \\
$50-59$ & acceptable \\
$40-49$ & marginal \\
$30-39$ & unfavourable \\
$20-29$ & very unfavourable \\
$10-19$ & extremely unfavourable \\
$-20-9$ & impossible \\
\hline
\end{tabular}

Source: Mieczkowski, Z.T. 1985.

The $m T C I$ index has improved the thermal relevance of the original TCI by integrating the most widely used and up-to-date thermal comfort index Physiologically Equivalent Temperature (PET) (HöPPE, P. 1999) into the CId and CIa components of the TCI instead of the ET (Kovács, A. et al. 2016, 2017; Kovács, A. 2017). PET takes into account the combination of four climate parameters (air temperature, air humidity, wind velocity, and thermal radiation) and personal factors, such as clothing and human activity, which both determine the thermophysiological effect of the atmospheric environment on the human body.

In addition to the shortcoming of the thermal aspect, the other disadvantage of the TCI is that the rating schemes of the sub-indices are arbitrary and had never been tested empirically against the perceptions and preferences of humans. Therefore, in the $m T C I$, a new PET rating system was developed and integrated into CId and CIa, which reflect the seasonally different thermal perception patterns of Hungarian residents. This modification improves the credibility of the thermal rating scores of the original TCI, thus enhancing the potential of TCI to evaluate the thermal comfort conditions of the atmospheric environment (Kovács, A. et al. 2016, 2017; Kovács, A. 2017). To achieve this, data from an extensive thermal comfort survey were used, which were collected from spring to autumn; therefore, the winter period is excluded from the analysis with $m$ TCI for Hungary. In $m T C I$, the PET rating scores of CId and CIa range from zero (unfavourable) to five (optimal). In practice, the CId and CIa sub-indices are derived utilising daily maximum and daily mean $P E T$ values, respectively.

The original rating system of $R, S$ and $W$ sub-indices, the calculation formula of the index (Eq. 1) and the overall evaluation system (Table 1) were not modified. Full details on the construction of TCI are presented in Mieczkowski, Z.T. (1985), Kovács, A. et al. (2016, 2017) and Kovícs, A. (2017), while the full conceptual and methodological aspects of the modification of TCI are available in Kovács, A. et al. $(2016,2017)$ and Kovács, A. (2017).

In this study, we present the $m$ TCI results on a monthly basis (from March to November). To achieve this, we used the monthly values (monthly means and monthly sum in the case of precipitation) of the seven necessary daily climate parameters. As the calculation of PET in the $m T C I$ requires some kind of thermal radiation data, global radiation or cloud cover 
data are also necessary. The daily maximum PET was calculated from daily maximum temperature, minimum relative humidity, mean wind speed and mean cloud cover, while the daily mean PET values were obtained from daily mean temperature, mean relative humidity, mean wind speed and mean cloud cover data. The PET values were determined using the RayMan radiation and bioclimate model (Matzarakis, A. et al. 2010).

We present the results for a thirty-year climate period describing the present climate conditions as well as for two climate periods that characterise the possible future conditions. Thus, we used multi-year mean monthly raw data, and from them, we calculated multi-year mean monthly mTCI values.

The $m$ TCI was first calculated for the reference period 1971-2000, which characterises the current climate conditions. For performing this calculation, the observational database CarpatClim-HU (BIHARI, Z. et al. 2017) developed by the Hungarian Meteorological Service (HMS) was used. The database contains grid point data with a horizontal spatial resolution of $0.1^{\circ} \times 0.1^{\circ}$ (approx. $10 \mathrm{~km}$ ) for the area of Hungary (covering the grid of $45.8^{\circ} \mathrm{N}-48.5^{\circ} \mathrm{N}$ and $\left.16.2^{\circ} \mathrm{E}-22.8^{\circ} \mathrm{E}\right)$. This $0.1^{\circ}$ resolution database represents 1,104 grid points across Hungary (Figure 2). These grid point values were generated from controlled,

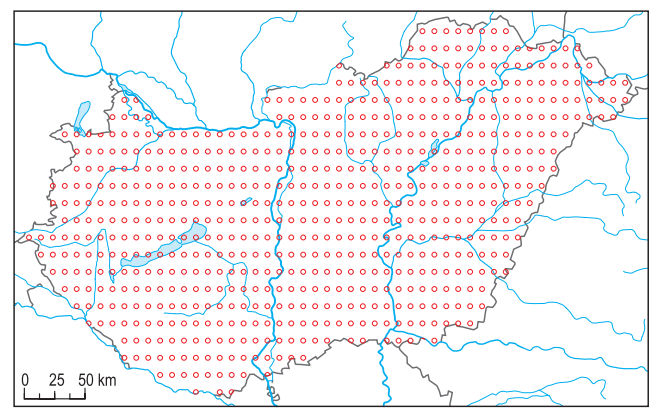

Fig. 2. The $0.1^{\circ} \times 0.1^{\circ}$ resolution grid of the homogenised, interpolated observational database CarpatClim-HU and the interpolated regional climate model simulations HIRHAM5 and RACMO22E. Source: SzÉPSzó, G. et al. 2016. homogenised meteorological measurement data, which were interpolated to the $0.1^{\circ}$ resolution grid and harmonised along national borders. The raw data were provided by the HMS, and we calculated the multi-year monthly $m$ TCI values from them.

The investigated climate models for evaluating future conditions were chosen from the EURO-CORDEX experiments (JАСOв, D. et al. 2014). EURO-CORDEX is the European branch of the international CORDEX initiative (GIorgi, F. et al. 2009) and contains climate change projections for Europe based on an ensemble of RCM simulations (https:// www.euro-cordex.net/). In EURO-CORDEX, the simulations have been conducted at two different spatial resolutions: the general CORDEX resolution of $0.44^{\circ}$ (EUR-44, approx. $50 \mathrm{~km}$ ) and a finer resolution of $0.11^{\circ}$ (EUR11 , approx. $12.5 \mathrm{~km}$ ). In order to quantify the tourism climate conditions for the area of Hungary, the small-scale EUR-11 experiments were selected. The data were obtained from the archives published and distributed via the Earth System Grid Federation (ESGF) under the project name CORDEX (CINQuini, L. et al. 2014). For the analysis, two RCMs driven by the same GCM were selected (Table 2).

The two selected RCMs are the HIRHAM5 (by the Danish Meteorological Institute, DMI) (Christensen, O.B. et al. 1998) and the RACMO22E (by the Royal Netherlands Meteorological Institute, KNMI) (vAN MeijgaARD, E. 2012). Their driving model was the EC-EARTH (by the Irish Centre for HighEnd Computing, ICHEC, http://www.glisaclimate.org/node/2238) (HAzELEGER, W. et al. 2010). The simulations with the RCP 4.5 and

Table 2. The climate model experiments used in the analysis

\begin{tabular}{c|c|c|c}
\hline $\begin{array}{c}\text { Driving } \\
\text { global } \\
\text { climate } \\
\text { model }\end{array}$ & $\begin{array}{c}\text { Regional } \\
\text { climate model }\end{array}$ & Institute & $\begin{array}{c}\text { Emission } \\
\text { scenario }\end{array}$ \\
\hline \multirow{2}{*}{ EC-EARTH } & HIRHAM5 & DMI & $\begin{array}{l}\text { RCP4.5 } \\
\text { RCP8.5 }\end{array}$ \\
\cline { 2 - 4 } & RACMO22E & KNMI & $\begin{array}{c}\text { RCP4.5 } \\
\text { RCP8.5 }\end{array}$ \\
\hline
\end{tabular}


RCP8.5 emission scenarios (Representative Concentration Pathways, Moss, R.H. et al. 2010) were used in both cases (see Table 2). These two scenarios are quite different in terms of possible greenhouse gas concentration trajectories. RCP4.5 is an intermediate stabilisation pathway in which radiative forcing is stabilised at $4.5 \mathrm{Wm}^{-2}$ in the year 2100. In RCP8.5, emissions continue to rise throughout the $21^{\text {st }}$ century, with radiative forcing reaching $8.5 \mathrm{Wm}^{-2}$ for 2100 .

In selecting these two models, the first important consideration was that the various data needed to calculate $m$ TCI be available. The second aspect was to select models with validation results being satisfying in terms of model error when comparing them with observations. Considering this aspect, we compared the monthly mean air temperature and monthly precipitation sum (which are two important parameters in $m T C I$ ) simulated by the two selected models to those based on the observations (CarpatClim-HU) for the reference period (1971-2000) for Hungary. Comparing the model results to the observed data, reasonable agreement can be observed (Figure 3). Thirdly, we selected model projections that show representative results (especially for air temperature and precipitation) to display the uncertainties correctly with the models. This aspect was studied through Taylor diagrams of the mean air temperature and precipitation sum for the reference period again. We compared 12 GCM-RCM com- binations from the EURO-CORDEX experiments to the observations (CarpatClim-HU), and the results demonstrate that the degree of correspondence between the models and observations is one of the highest in the two cases used (HIRHAM5 and RACMO22E) (Figure 4). During the model selection, we also took into account the results of Torma, Cs. Zs. (2019), KIs, A. et al. (2020) and Torma, Cs. Zs. et al. (2020) who validated several EUROCORDEX experiments (including HIRHAM5 and RACMO22E) against CarpatClim observations for the Carpathian Region.

For the assessment of future conditions, the 2071-2100 period was selected, while the reference period of the model experiments was the same as that of the observational database (1971-2000). The downloaded data were pre-processed with Climate Data Operator (CDO) in order to interpolate from the EUR-11 grid to the CarpatClim-HU grid (see Figure 2) and to get multi-year monthly averages from the raw data.

When evaluating projections for the future, it should be taken into account that the results of regional (and global) models are necessarily burdened with uncertainties; therefore the systematic model errors need to be eliminated somehow. Several methods exist to reduce these errors, of which we used the so-called delta method (HAwKINs, E. et al. 2013). This means that the future model results were not in themselves interpreted but relative to the models' own reference periods

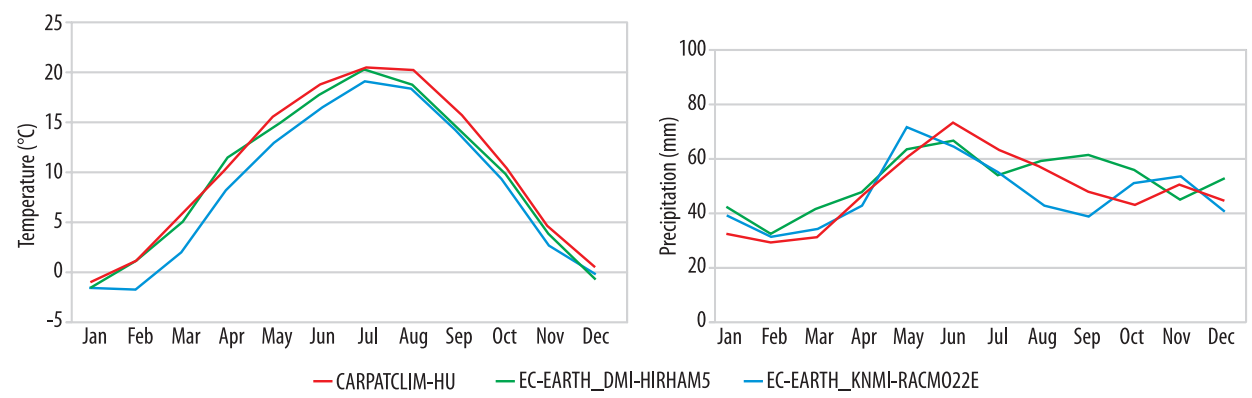

Fig. 3. Annual course of the monthly mean air temperature (left) and precipitation sum (right) of the RCMs HIRHAM5 andRACMO22E and of the observational database CarpatClim-HU for the reference period (1971-2000) for Hungary 

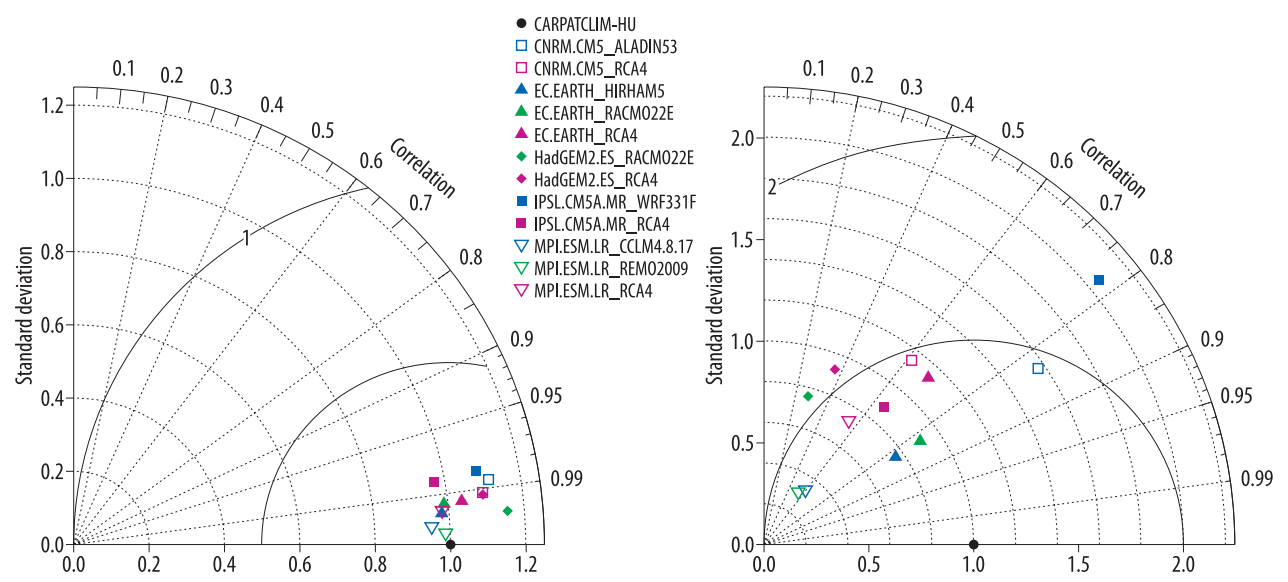

Fig. 4. Taylor diagrams of the mean air temperature (left) and precipitation sum (right) for 12 GCM-RCM combinations from the EURO-CORDEX experiments versus the observations CarpatClim-HU for the reference period (1971-2000) for Hungary

by specifying the change values. Thus, for each grid point and each variable of the models, we determined the differences between their future values (2071-2100) and their values for the reference period (1971-2000). We then added these changes to the observed data (CarpatClim-HU) from the reference period (1971-2000) to obtain the corrected future values of the given model.

We present the monthly $m$ TCI results at the district level for Hungary. The district is a small-scale administrative-territorial unit in Hungary; the analysis on that level can provide effective results for tourists, tourism professionals and decision-makers. To achieve this, after calculating the monthly values of $m T C I$ for each grid point, district averages were generated from them, and finally, the obtained spatial distribution was displayed on maps for each month.

\section{Results}

Mapping of $m$ TCI results was performed according to the descriptive category system shown in Table 1. This categorisation is more straightforward for the users than the raw values of $m$ TCI. Due to the low number of cases below the value 40 , these values were merged into a single category called 'unfavourable'. The outputs for the period 19712000 based on the CarpatClim-HU database are presented in Figure 5.

The most unpleasant month during the analysed period is November, with 'unfavourable' conditions in almost the whole country except the Southern Great Plain where 'marginal' conditions prevail. November is followed by March with mostly 'acceptable' conditions. In this month, only some mountainous regions remain 'marginal', while in some southern parts of the country 'good' conditions are already appearing. In April, there is a significant improvement in the tourism climate potential, reaching 'very good' conditions or even 'excellent' circumstances in the Great Plain. The climate potential remains similarly favourable in May, only a slight change in the spatial distribution is displayed. From June, a gradual decline is observed, which lasts until September. This means that the 'excellent' conditions are replaced with 'very good' in June, and even 'good' category appears in some places. For July and August, it can be observed that the 


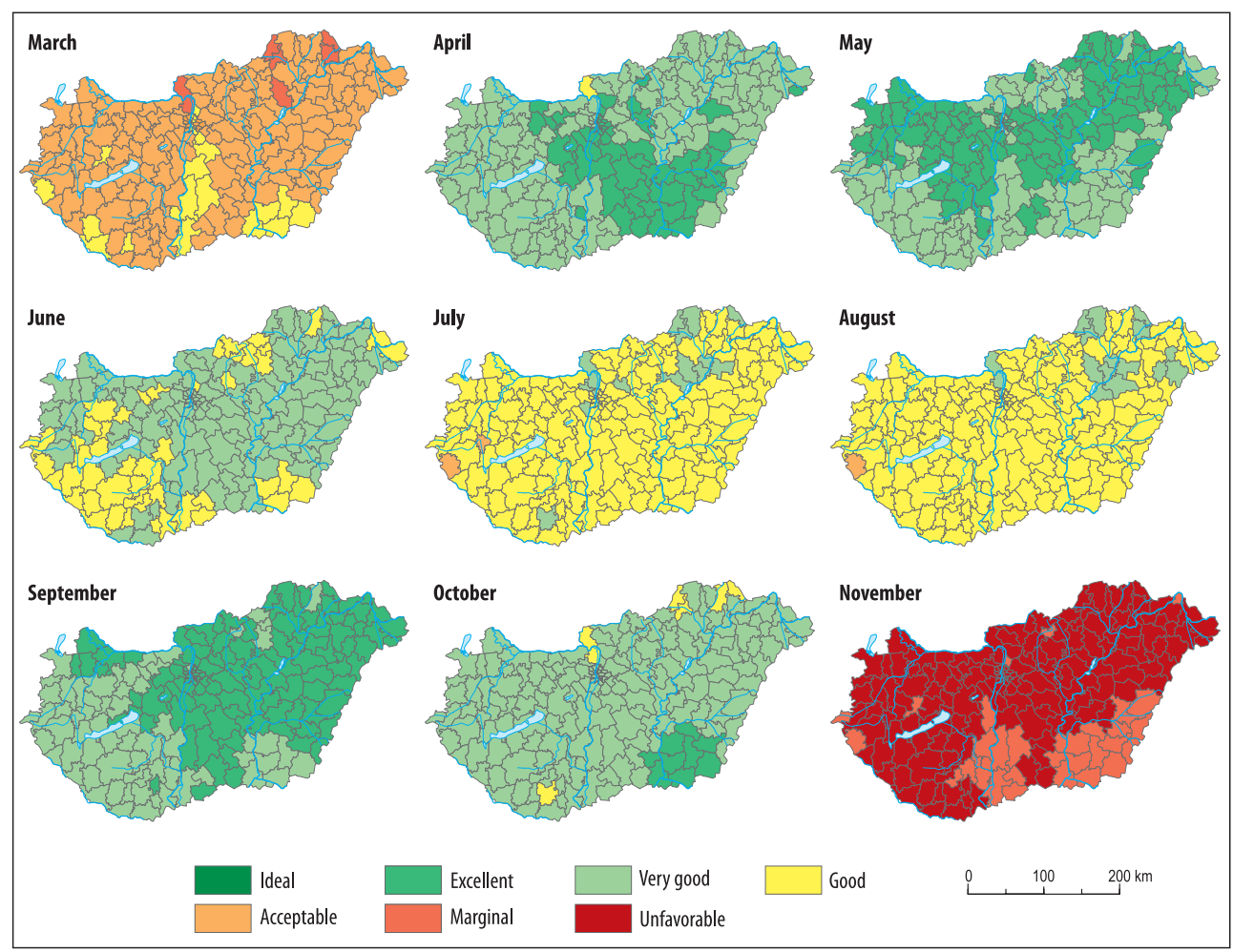

Fig. 5. Spatial distribution of $m$ TCI categories by district on a monthly basis for the period 1971-2000 based on CarpatClim-HU database

proportion of areas characterised only as 'good' is significantly increasing at the expense of a 'very good' evaluation. It is worth mentioning that these 'good' conditions also indicate favourable potential for outdoor activities. In September, there is a considerable recovery in the climate conditions, and more than half of the country is characterised with the 'excellent' category again. With this improvement, the spatial pattern of $m T C I$ becomes similar to that experienced in May. In October, a slight decrease in $m \mathrm{TCI}$ is starting. In this period, most parts of the country are characterised by 'very good' conditions. By November, a much more pronounced decline by 3-4 categories can be observed, reaching the 'unfavourable' or 'marginal' classification for outdoor activities (see Figure 5).
In summary, there is a significant improvement during the spring, but a slight decline from June to September. During the autumn, an improvement is detected again, while from November, the climate potential is decreasing. According to the classification of Scott, D. and McBoyle, G. (2001), who examined the potential annual courses of TCI, a bimodal structure emerges, which means that the spring and autumn have more favourable climate conditions than the summer period, which is in agreement with our results.

In relation to future trends in $m T C I$ distribution, we first analyse the output of HIRHAM5 simulation based on RCP4.5 scenario (Figure 6). According to the results, the pattern of $m T C I$ signals bimodal structure again because we find the most pleasant con- 


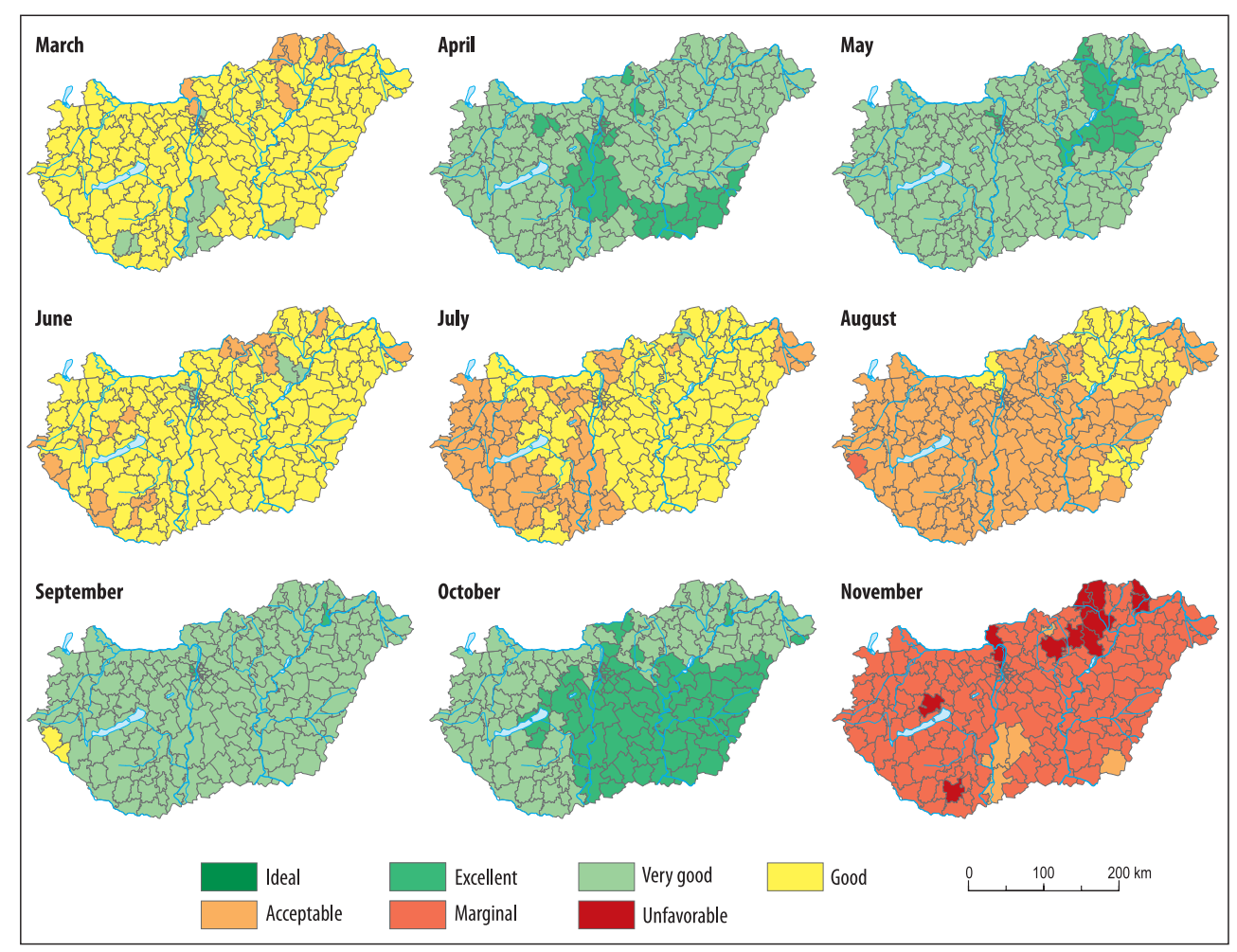

Fig. 6. Spatial distribution of $m$ TCI categories by district on a monthly basis for the period 2071-2100 based on the EC-EARTH driven HIRHAM5 simulation with RCP4.5 scenario

ditions in April, May, September and October with 'very good' or 'excellent' evaluation.

In March and November, a significant improvement will be probable compared to the reference period (1971-2000, CarpatClim$\mathrm{HU})$, which means a one-category change in most of the country (see Figure 5 and 6). In addition to these months, a similar improvement is expected in October in the Great Plain. In April, significant differences are not observed. However, from May to September, large parts of the country may experience a decline in climate potential by a category. Specifically, in May and September, most of the country will likely be classified as 'very good' instead of 'excellent'. In all months of the summer, the change in the mTCI pattern also shows an unfavourable trend. In
June, 'good' circumstances will be probable at the expense of 'very good', while in a few districts 'acceptable' conditions are already displayed. In the Transdanubian areas in July and most of the country in August, only 'acceptable' conditions may be experienced instead of 'good' potential (see Figure 5 and 6).

In conclusion, we can expect an increase of $m$ TCI with one category or in some cases, tourism climate conditions will remain unchanged in March, April, October and November. However, in the period between May and September, which has a significant tourist turnover in Hungary, there is a decline by a category or possibly stagnation in some places.

Bimodal annual structure of $m T C I$ is detected again when analysing the RACMO22E 


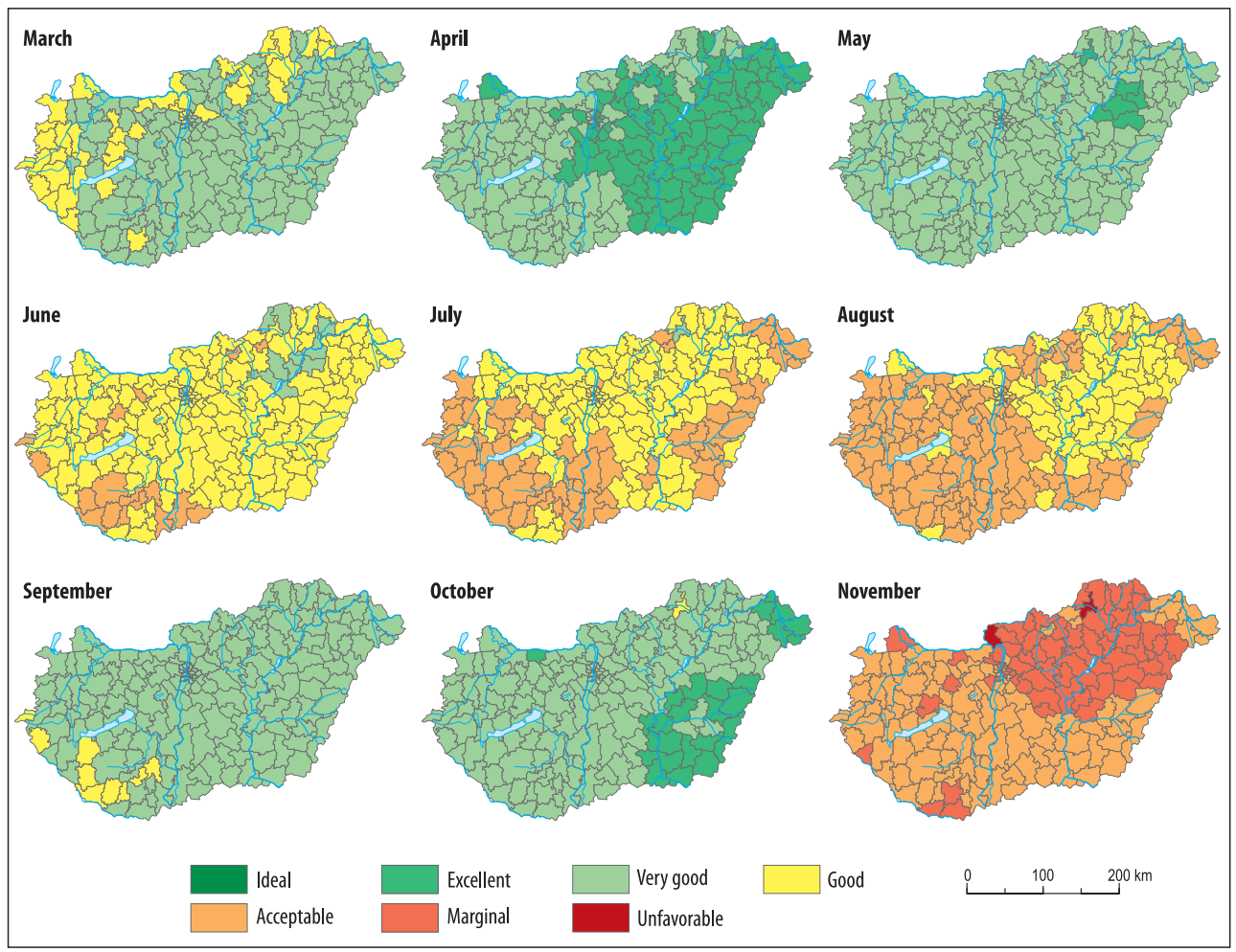

Fig. 7. Spatial distribution of $m$ TCI categories by district on a monthly basis for the period 2071-2100 based on the EC-EARTH driven RACMO22E simulation with RCP4.5 scenario

outputs based on RCP4.5 scenario (Figure 7). Considering the future projection, similar tendencies are found, as in the case of the HIRHAM5, RCP4.5 experiment (see Figure 6 and 7). Between them, only slight differences occur that do not exceed one category. The largest differences, more precisely category deviation for the largest area, are indicated for March, April, October and November. In March and November, RACMO22E indicates more pleasant conditions in a large part of Hungary than HIRHAM5. In April, a slight improvement is detected in the eastern half of the country compared to HIRHAM5 and also to the CarpatClim-HU results, while in October, a smaller area is affected by the most favourable conditions than in the case of the HIRHAM5 experiment. During the period from May to September, the tourism climate conditions based on the two models are almost identical; only the pattern in July and August indicates a slight deviation for the eastern part of Hungary.

The model experiment HIRHAM5 using the RCP8.5 scenario usually shows an improvement in the climate potential in March, April, October and November compared to the reference period (Figure 5 and 8 ). The change in March and November is particularly remarkable, as all areas of the country may experience conditions that are more favorable by one or two categories. In April and October, the conditions remain unchanged in Transdanubia and are more pleasant by a category in the eastern part of the country. From May to September, almost 


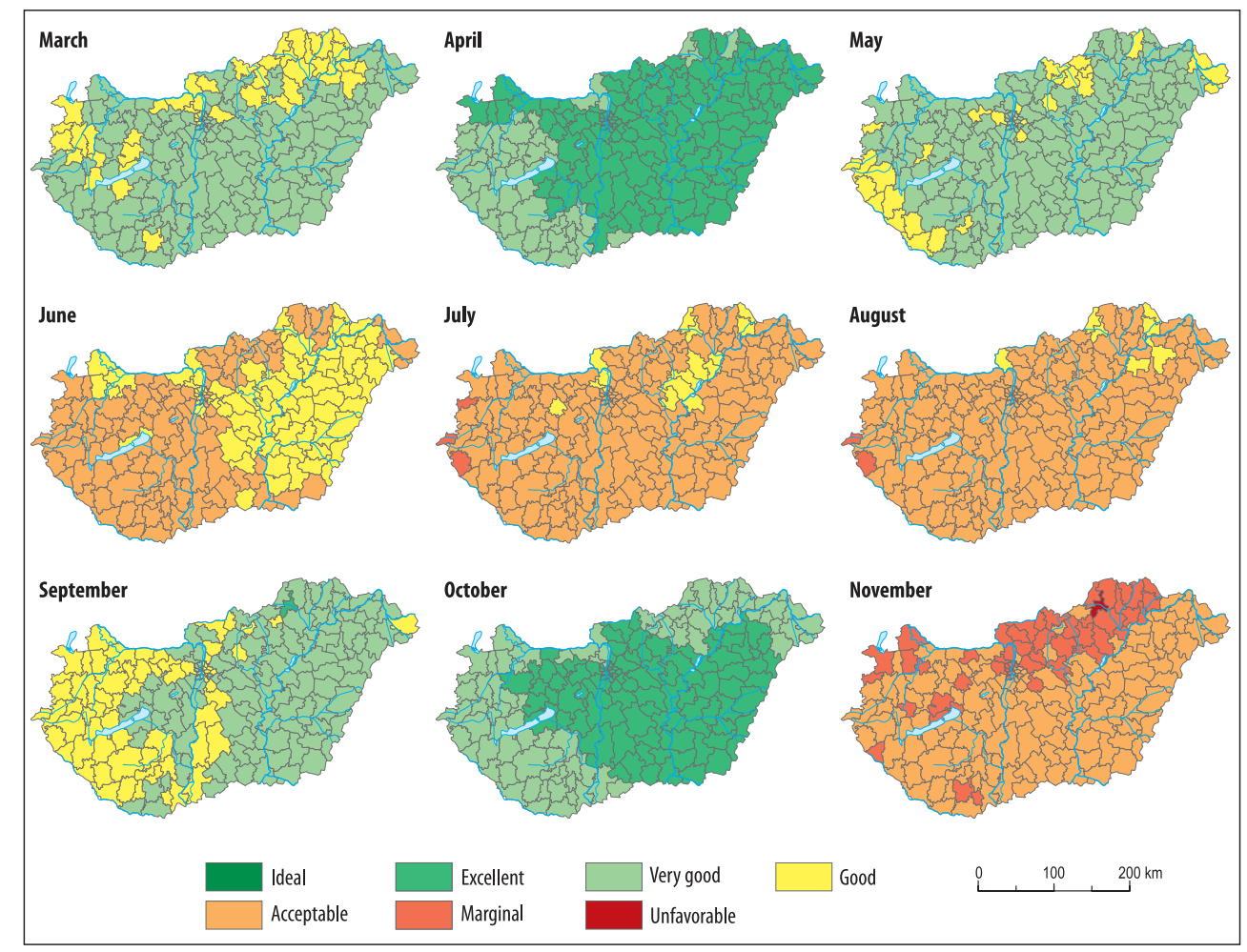

Fig. 8. Spatial distribution of $m T C I$ categories by the district on a monthly basis for the period 2071-2100 based on the EC-EARTH driven HIRHAM5 simulation with RCP8.5 scenario

all regions of the country may become less favourable typically by a category.

This scenario indicates larger changes or changes affecting larger areas in both (positive and negative) directions compared to the HIRHAM5, RCP4.5 experiment (Figure 6 and 8). Specifically, 'very good' conditions prevail instead of 'good' in March, and there are 'acceptable' conditions instead of 'marginal' in November. In April and October, the ratio of the 'excellent' classification is higher in the RCP8.5 case. In May and September, when an unfavourable tendency is observed, some parts of the country are characterised with 'good' conditions in place of 'very good'. During the summer months, 'acceptable' became the dominant category in most parts of Hungary at the expense of 'good' that was typical for RCP4.5.
The tendencies shown by the RACMO22E, RCP8.5 experiment are consistent with the previous findings (Figure 9). The output of this model is similar to the HIRHAM5, RCP8.5 results (Figure 8 and 9). There are at most one-category differences between them. The projection for the summer period is almost the same, especially for July and August. The highest differences occur in spring and autumn, though they affect small areas only and never exceed one category.

Similar to the HIRHAM5 case, the future changes are typically larger in RACMO22E with RCP8.5 compared to RACMO22E with RCP4.5 (see Figure 7 and 9). In particular, the decline between May and September is more significant in RCP8.5; that is, the ratio of districts with only 'good' ('acceptable') potential is higher in May and September (in June, July 


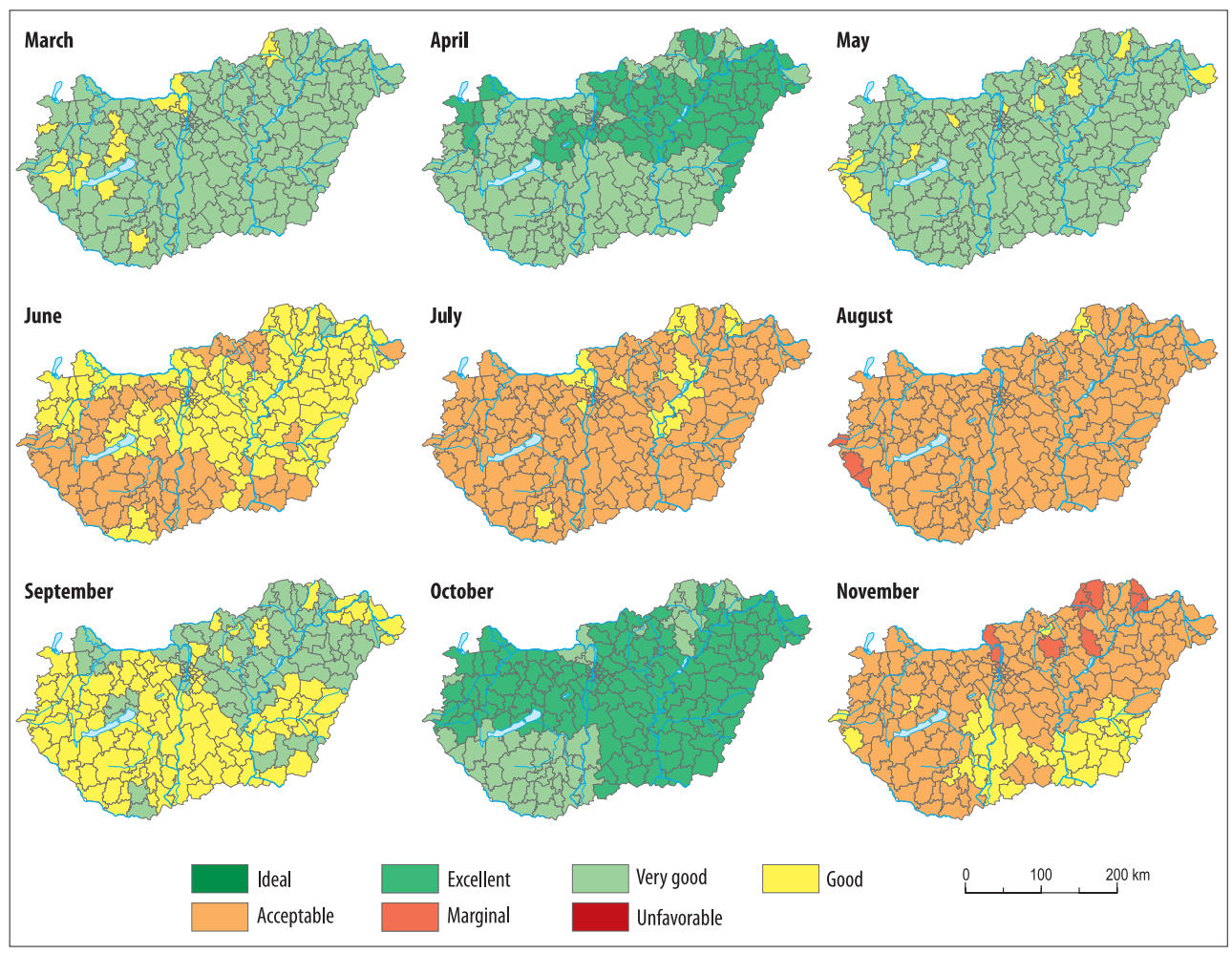

Fig. 9. Spatial distribution of $m$ TCI categories by district on a monthly basis for the period 2071-2100 based on the EC-EARTH driven RACMO22E simulation with RCP8.5 scenario

and August). Further, the degree of improvement in March, October and November is also more considerable in the RCP8.5 case.

\section{Summary and concluding remarks}

According to the current and future spatial patterns of tourism climate conditions in Hungary through observations and regional climate model data, the following outlines can be drawn:

- The annual course of the present and future conditions is bimodal in all cases, that is, the most favourable circumstances are found in spring and autumn, while in the summer period, a decline in climate potential is observed.
- According to future projections, the tourism climate potential for March, April, October and November usually brings an improvement, while between May and September, a decline is generally expected.

- For a given RCP emission scenario, the expected trend is quite similar for the HIRHAM5 and RACMO22E experiments, with at most one-category differences between them, mainly during the transition seasons.

- For a given climate model, using the RCP8.5 scenario, the changes in both directions are typically larger or they affect a larger area than in the case of RCP4.5.

The obtained results are consistent with the outcomes of the investigation carried out in the previous CRIGiS-NAGiS project 
(BIHARI, Z. et al. 2015) in which also the current and future tourism climate potential for Hungary was evaluated using the $m T C I$ index (among others) and by almost the same methodology (Bihari, Z. et al. 2015; Kovács, A. 2017; Kovács, A. et al. 2017). However, that assessment was based on the output of a single RCM simulation and a single emission scenario from the former scenario family (ALADIN-Climate model, A1B scenario). According to that investigation, March, April, October and November brought an improvement, while the other months a decline, which is similar to the results of this study. In this study, we used a small multimodel ensemble of simulations chosen from a more up-to-date climate model ensemble, based on multiple and up-to-date scenarios implemented with multiple regional climate models. This method could be an initial step to ensure a balanced presentation of uncertainties and to interpret the outcomes of exposure and impact studies properly.

Comparing our results with previously published international examples is a difficult task. On the one hand, the use of the $m$ TCI index is not yet widespread. This measure has been adapted to the Hungarian climate conditions, though the applied methodology can be effective in any country or region, but this process requires an extended, long-term thermal comfort measurement and questionnaire survey (Kovács, A. et al. 2016). The credible comparability is also hampered by differences in the baseline databases used to determine the various tourism climatological indicators (basic data, observations, models, study periods) and by the variety of data processing and analysis methods, as well as the different presentation of the results (mapping, scaling, time scale). In many cases, the lack of basic information in the published articles also makes comparison difficult (Kovács, A. 2017). Nevertheless, since the $m T C I$ index is similar to TCI in many aspects (structure, calculation) their comparison is reasonable (Kovács, A. 2017). The bimodal structure of $m$ TCI and the future tendencies in the different periods of the year demonstrated in this study are in reasonable accordance with the international findings using the original TCI (e.g. ScotT, D. et al. 2004; Nicholls, S. and Amelung, B. 2008; Perch-Nielsen, S.L. et al. 2010; Amelung, B. and Moreno, A. 2012; Kovács, A. 2017).

Our results demonstrate that climate change will have an obvious impact on tourism potential in Hungary, and therefore tourism strategy development has to take into account this effect more than before. Methods and practices to adapt to climate change should be used in both the demand and supply side of tourism. The improvement of climatic conditions in spring and autumn has the potential to extend the outdoor tourist season, which is a key element of adaptation to the altered conditions. The means of diversifying the tourism economy can be the development of different outdoor and partly indoor services usable in extended periods, too. In Hungary, cultural and gastronomic festivals, health tourism (especially the development of tourism-based medical services) or strengthening business and conference tourism can be feasible tools. The unfavourable tendency shown in summer, which is mainly due to the increasing frequency of warm (or hot) days and extreme events, may encourage tourism operators to develop non-weather and non-climate sensitive products. Themed walks, theme or leisure parks, visitor centres, indoor event spaces, indoor baths, spas or water parks can be effective solutions for this purpose. In each case, the infrastructure for hosting the tourists (accommodation, hospitality) should be adapted in space and time to the altered demand.

When evaluating the results of this study, it should be kept in mind that, in addition to climatic conditions, many social and economic factors and mechanisms (e.g. accessibility and distance, transport costs, budget) play a decisive role in the dynamics of tourism. In addition, several natural or cultural elements influence the motivation of tourists and decision-making (e.g. geology, hydrology, vegetation, historical monuments, celebrations) (Gómez Martín, B. 2005). Uncertainties could emerge not only from the 
prediction of climate conditions and climate change but also from the estimation of the natural, social and economic factors affecting tourism, and, thus, the same impacts of climate change.

Acknowledgements: We acknowledge the World Climate Research Programme's Working Group on Regional Climate and the Working Group on Coupled Modelling, the former coordinating body of CORDEX. We also thank the EURO-CORDEX climate modelling groups (listed in Table 2 of this paper) for producing and making available their model output. We also acknowledge the Earth System Grid Federation infrastructure, an international effort led by the U.S. Department of Energy's Program for Climate Model Diagnosis and Intercomparison. The first author was supported by the ÚNKP-20-4SZTE-617 New National Excellence Program of the Ministry for Innovation and Technology from the source of the National Research, Development and Innovation Fund.

\section{REFERENCES}

Amelung, B. and Moreno, A. 2012. Costing the impact of climate change on tourism in Europe: results of the PESETA project. Climatic Change 112. (1): 83-100.

Amelung, B. and Nicholls, S. 2014. Implications of climate change for tourism in Australia. Tourism Management 41. 228-244.

Bihari, Z., Hoffmann, L., Lakatos, M. et al. 2015. Vulnerability/Impact studies with a focus on tourism and critical infrastructures. Summary of the project results. CRIGiS project, Budapest, Hungarian Meteorological Service. Available at https://www. met.hu/KRITeR/en/publikacio/

Bihari, Z., Lakatos, M. and Szentimrey, T. 2017. Felszíni megfigyelésekből készített rácsponti adatbázisok az Országos Meteorológiai Szolgálatnál (Gridded data series prepared from surface observation at Hungarian Meteorological Service). Légkör 62. (4): 148-151.

Christensen, O.B., Christensen, J.H., Machenhauer, B. and Botzet, M. 1998. Very high-resolution regional climate simulations over Scandinavia - present climate. Journal of Climate 11. (12): 3204-3229.

Cinquini, L., Crichton, D., Mattmann et al. 2014. The Earth System Grid Federation: An open infrastructure for access to distributed geospatial data. Future Generation Computer Systems 36. 400-417.

de Freitas, C.R., Scott, D. and McBoyle, G. 2008. A second generation climate index for tourism (CIT): specification and verification. International Journal of Biometeorology 52. (5): 399-407.
Endler, C., Oehler, K. and Matzarakis, A. 2010. Vertical gradient of climate change and climate tourism conditions in the Black Forest. International Journal of Biometeorology 54. (1): 45-61.

Gavrilov, M.B., Radaković, M.G., Sipos, Gy. et al. 2020. Aridity in the Central and Southern Pannonian Basin. Atmosphere 11. (12): 1269.

Giorgi, F., Jones, C. and Asrar, G.R. 2009. Addressing climate information needs at the regional level: the CORDEX framework. WMO Bulletin 58. (3): 175-183.

Gómez Martín, B. 2005. Weather, climate and tourism. A geographical perspective. Annals of Tourism Research 32. (3): 571-591.

Hamilton, J.M. and LAU, M.A. 2005. The role of climate information in tourist destination choice decision-making. In Tourism and Global Environmental Change. Eds.: Gössling, S. and Hall, C.M., London, Routledge, 229-250.

Hawkins, E., Osborne, T.M., Ho, C.K. and Challinor, A.J. 2013. Calibration and bias correction of climate projections for crop modelling: An idealised case study over Europe. Agricultural and Forest Meteorology 170. 19-31.

Hazeleger, W., Severijns, C., Semmler, T. et al. 2010. EC-Earth: A seamless Earth-system prediction approach in action. Bulletin of the American Meteorological Society 91. (10): 1357-1364.

Houghten, F.C. and Yaglou, C.P. 1923. Determining equal comfort lines. Journal of the American Society of Heating and Ventilating Engineers 29. 165-176.

Höppe, P. 1999. The physiological equivalent temperature - an universal index for the biometeorological assessment of the thermal environment. International Journal of Biometeorology 43. (2): 71-75.

IPCC 2007. Climate Change 2007: Impacts, Adaptation and Vulnerability. Contribution of Working Group II to the Fourth Assessment Report of the Intergovernmental Panel on Climate Change. Eds.: PArry, M.L. et al., Cambridge, Cambridge University Press.

Jacob, D., Petersen, J., Eggert, B. et al. 2014. EUROCORDEX: new high-resolution climate change projections for European impact research. Regional Environmental Change 14. (2): 563-578.

Kis, A., Pongrácz, R., Bartholy, J., Gocic, M., Milanovic, M. and Trajkovic, S. 2020. Multiscenario and multi-model ensemble of regional climate change projections for the plain areas of the Pannonian Basin. Időjárás 124. (2): 157-190.

Kovács, A. and UnGER, J. 2014a. Modification of the Tourism Climatic Index to Central European climatic conditions - examples. Időjárás 118. (2): 147-166.

Kovács, A. and Unger, J. 2014b. Analysis of tourism climatic conditions in Hungary considering the subjective thermal sensation characteristics of the south-Hungarian residents. Acta Climatologica and Chorologica Universitatis Szegediensis 47-48. 77-84. 
Kovács, A., Unger, J., Gál, C.V. and Kántor, N. 2016. Adjustment of the thermal component of two tourism climatological assessment tools using thermal perception and preference surveys from Hungary. Theoretical and Applied Climatology 125. (1-2): 113-130.

Kovács, A. 2017. Evaluation of the tourism climate potential based on original and improved methods adapted to Hungarian population (in Hungarian). PhD Thesis, Doctoral School of Geosciences. Szeged, University of Szeged. Available at http://doktori.bibl.u-szeged. hu/id/eprint/3860/

Kovács, A., Németh, Á., Unger, J. and Kántor, N. 2017. Tourism climatic conditions of Hungary present situation and assessment of future changes. Időjárás 121. (1): 79-99.

KozAK, M. 2002. Comparative analysis of tourist motivations by nationality and destinations. Tourism Management 23. (3): 221-232.

Lakatos, M., Bihari, Z., Szentimrey, T., Spinoni, J. and Szalai, S. 2016. Analyses of temperature extremes in the Carpathian Region in the period 1961-2010. Időjárás 120. (1): 41-51.

LoHmann, M. and KaIM, E. 1999. Weather and holiday destination preferences image, attitude and experience. The Tourist Review 54. (2): 54-64.

Matzarakis, A. 2007. Assessment method for climate and tourism based on daily data. In Developments in Tourism Climatology. Eds.: Matzarakis, A., DE FreitAs, C.R. and ScotT, D., Freiburg, International Society of Biometeorology, Commission on Climate, Tourism and Recreation, 52-58.

Matzarakis, A., Rutz, F. and Mayer, H. 2010. Modelling radiation fluxes in simple and complex environments: basics of the RayMan model. International Journal of Biometeorology 54. (2): 131-139.

Mieczкowski, Z.T. 1985. The tourism climatic index: a method of evaluating world climates for tourism. The Canadian Geographer 29. (3): 220-233.

Moss, R.H., Edmonds, J.A., Hibbard, K.A. et al. 2010. The next generation of scenarios for climate change research and assessment. Nature 463. 747-756.

Németh, Á. 2013. Estimation of tourism climate in the Lake Balaton Region, Hungary. Journal of Environmental Geography 6. (1-2): 49-55.

Nicholls, S. and Amelung, B. 2008. Climate change and tourism in Northwestern Europe: Impacts and adaptation. Tourism Analysis 13. (1): 21-31.

Pálvölgyi, T., Czira, T., Dobozi, E., Rideg, A. and Schneller, K. 2010. A kistérségi szintü éghajlatváltozási sérülékenység vizsgálat módszere és eredményei (Method and results of the climate change vulnerability investigations at sub-regional level). KLÍMA-21 Füzetek 62. 88-102.

Perch-Nielsen, S.L., Amelung, B. and Knutti, R. 2010. Future climate resources for tourism in Europe based on the daily tourism climatic index. Climatic Change 103. (3-4): 363-381.
Perry, A.H. 1997. Recreation and tourism. In Applied Climatology: Principles and Practice. Eds.: Thompson, R.D. and Perry, A., London, Routledge, 240-248.

Rutт,, M. and Scoтt, D. 2014. Thermal range of coastal tourism resort microclimates. Tourism Geographies 16. (3): 346-363.

Schneider, S.H., Semenov, S., Patwardhan, A. et al. 2007. Assessing key vulnerabilities and the risk from climate change. In Climate Change 2007: Impacts, Adaptation and Vulnerability. Contribution of Working Group II to the Fourth Assessment Report of the Intergovernmental Panel on Climate Change. Eds.: Parry, M.L., Canziani, O.F., Palutikof, J.P., van Der Linden, P.J. and Hanson, C.E., Cambridge, Cambridge University Press, 779-810.

Scott, D. and McBoyle, G. 2001. Using a 'tourism climate index' to examine the implications of climate change for climate as a tourism resource. In Proceedings of the First International Workshop on Climate, Tourism and Recreation. Eds.: Matzarakis, A. and DE Freitas, C.R., Halkidiki, International Society of Biometeorology, Commission on Climate, Tourism and Recreation, 69-88.

Scott, D., McBoyle, G. and Schwartzentruber, M. 2004. Climate change and the distribution of climatic resources for tourism in North America. Climate Research 27. (2): 105-117.

Scotт, D. and Lemieux, C. 2010. Weather and climate information for tourism. Procedia Environmental Sciences 1. 146-183.

Scott, D., Hall, C.M. and Gössling, S. 2012. Tourism and Climate Change: Impacts, Adaptation and Mitigation. Abingdon, Routledge.

Scott, D., Rutty, M., Amelung, B. and TAng, M. 2016. An inter-comparison of the Holiday Climate Index (HCI) and the Tourism Climate Index (TCI) in Europe. Atmosphere 7. 80.

Spinoni, J., Antofie, T., Barbosa, P., Bihari, Z., Lakatos, M., Szalai, S., Szentimrey, T. and Vogt, J. 2013. An overview of drought events in the Carpathian Region in 1961-2010. Advances in Science and Research 10. 21-32.

Spinoni, J., Szalai, S., Szentimrey, T. et al. 2015. Climate of the Carpathian Region in the period 1961-2010: climatologies and trends of 10 variables. International Journal of Climatology 35. (7): 1322-1341.

SüTő, A. and FEJEs, L. 2019. A turizmus ágazat jelenlegi és potenciális éghajlati sérülékenységének területi különbségei Magyarországon (Territorial differences in existing and potential climate vulnerability of the tourism sector in Hungary). Tér és Társadalom 33. (3): 108-126.

SzÉpszó, G., Illy, T. and Szabó, P. 2016. A regionális klímamodellek eredményeinek utó-feldolgozása és a NATéR számára szükséges paraméterek elóállitása (Postprocessing of regional climate model results to prepare the climate parameters for NAGiS). RCMGiS project, Budapest, Hungarian Meteorological 
Service. Available at https://www.met.hu/RCMTeR/ en/publikacio/

Torma, Cs.Zs. 2019. Detailed validation of EUROCORDEX and Med-CORDEX regional climate model ensembles over the Carpathian Region. Időjárás 123. (2): 217-240.

Torma, Cs.Zs., Kis, A. and Pongrácz, R. 2020. Evaluation of EURO-CORDEX and Med-CORDEX precipitation simulations for the Carpathian Region: Bias corrected data and projected changes. Idójárás 124. (1): 25-46.
UNWTO 2008. Climate change and tourism-Responding to global challenges. Madrid, World Tourism Organization and United Nations Environment Programme. Available at https://www.e-unwto. org/doi/epdf/10.18111/9789284412341

van MeijgaArd, E. 2012. Refinement and application of a regional atmospheric model for climate scenario calculations of Western Europe. Nieuwegein, Programme Office Climate Changes Spatial Planning (OCLC: 819640773). 
